\title{
PELATIHAN PEMBUATAN ALAT PERAGA MATEMATIKA DAN IPA BAGI GURU-GURU SD ANA MARITIM SURABAYA
}

\author{
Oleh: \\ Ika Kurniasari ${ }^{1}$, Affiati Oktaviarina², Dimas Avian Maulana ${ }^{3}$ \\ 1,2,3 Jurusan Matematika FMIPA Unesa \\ 1ikakurniasari@unesa.ac.id
}

\begin{abstract}
Abstrak
Pada tingkat perkembangan kognitif, siswa sekolah dasar (SD) memerlukan benda nyata pada proses pembelajarannya. Hal ini berdampak pada guru SD yang harus mampu membuat alat peraga sendiri. Tujuan pengabdian ini untuk memberikan informasi kepada guru-guru SD Ana Maritim Surabaya tentang pembuatan alat peraga matematika dan IPA yang mudah. Pelaksanaan dalam pelatihan ini, peserta dibentuk kelompok dan setiap kelompok terdiri dari tiga-empat peserta, sehingga terbentuk tiga kelompok. Tiap kelompok mendapatkan alat dan bahan yang diperlukan untuk membuat alat peraga. Peserta membuat alat peraga sesuai arahan yang ada pada hand-out yang diberikan. Hasil pelatihan ini, yaitu (1) peserta membuat alat peraga matematika dengan bahan dari kertas, yaitu koin bilangan bulat dan berbagai bentuk bangun datar dan (2) Tentang alat peraga IPA, peserta membuat kaleng loncat dan air warna-warni di dalam botol.
\end{abstract}

Kata Kunci: Alat Peraga Matematika, Alat Peraga IPA

Abstract

In the cognitive development, students of elementary school need a real object in the learning process which has an impact on elementary school teachers who have to be able to make their own properties. The purpose of this community service is to provide information to teachers of SD Ana Maritim Surabaya to make the simple and easy media. Stages took in the process are: the participants formed a group of three and each group consists of three or four participants. Each group got the tools and materials needed to make props. Participants created props according to the directions available on given hand-out. The result of this community services are (1) the participants are making mathematical props using paper--coins integer and various forms of two-dimensional figure and (2) for Science media, participants created jumping can and coloured water in bottles.

Keywords: Mathematics media, science media

\section{PENDAHULUAN}

Alat peraga sangat diperlukan bagi siswa di jenjang pendidikan sekolah dasar (SD). Hal ini karena siswa pada jenjang SD berada pada tingkat perkembangan kognitif pra-operasional dan operasi konkrit. Pada tingkat perkembangan kognitif ini siswa memerlukan benda nyata pada proses pembelajarannya.

Pelatihan ini bertujuan untuk memberikan informasi kepada guru-guru SD Ana Maritim Pondok Maritim 1B bahwa membuat/mengadakan alat peraga tidaklah sulit dan mahal. Alat peraga yang akan kami latihkan adalah alat peraga untuk mata pelajaran matematika dan ilmu pengetahuan alam (IPA). Alat peraga ini dibuat dari bahan-bahan yang mudah didapat di sekeliling sekolah/lingkungan siswa, sehingga guru-siswa dapat langsung membuat sendiri dan menggunakan dalam proses pembelajaran.
Alat peraga untuk mata pelajaran matematika yang diberikan, yaitu materi geometri dan materi bilangan. Pada materi geometri mengenalkan alat peraga bangun datar dan bangun ruang sedangkan untuk materi bilangan alat peraga kancing bilangan bulat atau kartu bilangan bulat atau gerakan bilangan bulat dan rumah perkalian. Untuk alat peraga IPA berupa materi tekanan dan materi massa jenis zat cair. Pada materi tekanan mengenalkan alat peraga tekanan pada atmosfer dan hukum gas ideal sedangkan pada materi massa jenis zat cair mengenalkan hukum Archimedes dan berbagai macam massa jenis zat cair. Alat-alat peraga tersebut dapat langsung diterapkan dalam pembelajaran.

Pelaksanaan dalam pelatihan ini tidak semua alat peraga disajikan secara langsung kepada peserta, tetapi tim pengabdian memberikan alat dan bahan yang diperlukan kemudian peserta mencoba alat dan bahan tersebut untuk dijadikan sebagai alat-alat peraga matematika 
dan IPA. Dari alat dan bahan yang diberikan, peserta tidak dapat langsung membuat alat peraga dari bahan yang diberikan. Oleh karena itu, tim PKM memberikan hand out dan melatihkan membuat alat peraga dari alat dan bahan yang disediakan dan/atau mendapatkan alat dan bahan tersebut di sekitar sekolah.

\section{METODE PELAKSANAAN}

Pelatihan ini diikuti oleh seluruh guru kelas SD Ana Maritim Pondok Maritim I B. Pelatihan ini akan dilaksanakan sebanyak 2 (dua) kali tatap muka. Tatap muka yang pertama membuat alat peraga untuk mata pelajaran matematika dan IPA. Tatap muka kedua melihat penggunaan alat peraga yang telah dibuat dalam proses pembelajaran matematika dan IPA. Untuk tatap muka kedua bukanlah sasaran kegiatan ini. Berikut adalah alur kegiatan pengabdian yang dapat dilihat pada gambar 1 .

Tahap Persiapan meliputi: melakukan koordinasi dengan pihak sekolah, membuat hand-out alat peraga matematika dan IPA serta membuat angket respon peserta

Tahap Pelaksanaan melaksanakan kegiatan pengabdian masyarakat sesuai dengan hasil kesepakatan dengan pihak sekolah meliputi pembuatan alat peraga matematika dan IPA serta sebagai tambahan yaitu melihat aplikasi dari alat peraga yang dibuat pada pembelajaran di kelas.

Gambar 1. Alur Kegiatan Pengabdian Masyarakat

\section{HASIL DAN PEMBAHASAN}

Hasil yang didapat dari kegiatan pengabdian pada masyarakat ini terdiri dari tiga kegiatan, yaitu persiapan, pelaksanaan dan pengaplikasian di kelas. Berikut akan dipaparkan masing-masing kegiatan tersebut:

1. Persiapan

Pada kegiatan ini persiapan yang dilakukan adalah melakukan koordinasi dengan pihak sekolah dengan membawa proposal dan surat permohonan. Hasil yang didapat berupa kesepakatan pelaksanaan pada hari Sabtu tanggal 30 Juli 2016 untuk pelatihan pembuatan alat peraga yang mudah dan murah. Kegiatan pengaplikasian di kelas setelah tanggal 30 Juli 2016 disesuaikan dengan jadwal mengajar guru kelas hasil kesepakatan. Setelah mendapatkan hari dan tanggal pelaksanaan, Tim PKM menyusun hand out alat peraga dan instrumen angket respon peserta yang akan digunakan pada saat pelaksanan yang diperlukan. Selain itu mengkoordinasikan pembagian tugas pada saat pelaksanaan sebagai penyaji materi/narasumber dan dicantumkan pada susunan acara. Dalam pelaksanaan ini dibantu oleh seorang mahasiswa untuk tenaga administrasi dalam pelaksanaan kegiatan ini.

2. Pelaksanaan

Pelatihan pembuatan alat peraga dilaksanakan pada hari Sabtu tanggal 30 Juli 2016 di SD Ana Maritim Surabaya dengan diikuti oleh delapan orang guru kelas, tiga narasumber dan seorang tenaga administrasi. Pelaksanaan sesuai dengan susunan acara yang telah dibuat.

Diawal pelaksanaan kegiatan ini dibuka oleh kepala sekolah SD Ana Maritim Surabaya diikuti oleh ketua PKM Unesa. Selanjutnya mulai dilaksanakan kegiatan pelatihan dengan cara Tim PKM memberikan alat dan bahan di depan kelas. Peserta dibentuk menjadi empat kelompok dengan masing-masing kelompok terdiri dari dua orang peserta. Alat dan bahan yang diberikan yang pertama adalah alat dan bahan untuk alat peraga matematika. Alat dan bahan yang dibagikan meliputi: batang korek api, kawat, karet gelang, plastisin, kertas lipat, tali, gunting, bolpoint, rumah perkalian dan rumah penjumlahan. Alat dan bahan untuk alat peraga IPA mencakup: air, gelas bening, kertas karton, korek api, lilin, plastisin, piring kecil, pewarna makanan, baby oil, corong, dan botol plastic/kaca. Dari alat dan bahan yang disajikan, setelah didemonstrasikan dalam membuat satu alat peraga matematika maupun alat peraga IPA, peserta mampu membuat satu alat peraga matematika serta satu alat peraga IPA dari alat dan bahan yang disediakan.

3. Pengaplikasian di kelas

Setelah didapatkan pelatihan pembuatan alat peraga, dua peserta dipilih untuk mempraktekkan dalam pembelajaran di kelas. Dalam hal ini peserta yang ditunjuk adalah guru kelas 5 dan guru kelas 4 . Guru kelas 5 mempraktekkan alat peraga matematika pada materi bilangan, yaitu menggunakan alat gerak, sedangkan guru kelas 4 mempraktekkan alat peraga materi massa jenis zat cair.

Pada kegiatan persiapan tim PKM menyusun alat peraga yang dapat diaplikasikan untuk siswa SD yang alat dan bahannya mudah ditemukan (dibeli) dan murah harganya. Tim PKM menekankan alat dan bahan mudah ditemukan dan murah harganya karena sekolah yang menjadi mitra tergolong sekolah swasta yang tidak terlalu 
bagus dalam hal dana/biaya. Penyusunan alat peraga yang disajikan pada hand out merupakan alat peraga yang langsung dapat diaplikasikan kepada siswa SD. Dalam hal ini tim PKM tidak mengalami kendala yang berarti karena mendapatkan dukungan oleh semua Tim PKM.

Pada saat pelaksanaan peserta dibentuk menjadi empat kelompok dengan masingmasing kelompok terdiri dari dua orang peserta. Peserta awalnya mengalami kesulitan setelah tim PKM membagikan atau memberi alat dan bahan untuk dibuat alat peraga oleh peserta. Delapan orang peserta belum mampu membuat alat peraga dari alat dan bahan yang disediakan oleh karena itu tim PKM akhirnya membagikan hand out dan mempraktekkan pembuatan alat peraga. Hasilnya semua peserta mampu mempraktekkan atau membuat alat peraga sendiri. Pada gambar 2 dapat dilihat bahwa peserta mempraktekkan alat peraga matematika, yaitu materi bilangan alat peraga IPA. Lalu tim PKM meminta peserta untuk membuat sendiri alat peraga matematika dan alat peraga IPA tersebut.

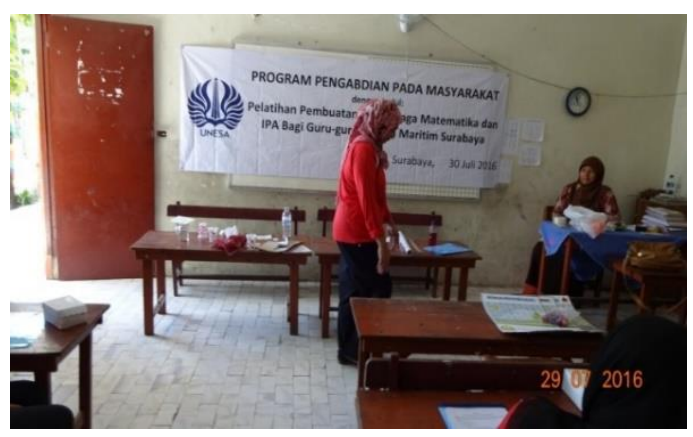

Gambar 2. Praktek Alat Peraga Matematika

Ternyata tiap kelompok peserta hanya mampu membuat satu alat peraga matematika yaitu pada materi bilangan dan satu alat peraga IPA pada materi tekanan. Pada alat peraga matematika, guru membuat alat peraga operasi bilangan bulat dengan bahan kertas lipat. Pada alat peraga IPA materi hukum Archimedes menggunakan alat dan bahan berupa saos kemasan plastik, air dan botol.

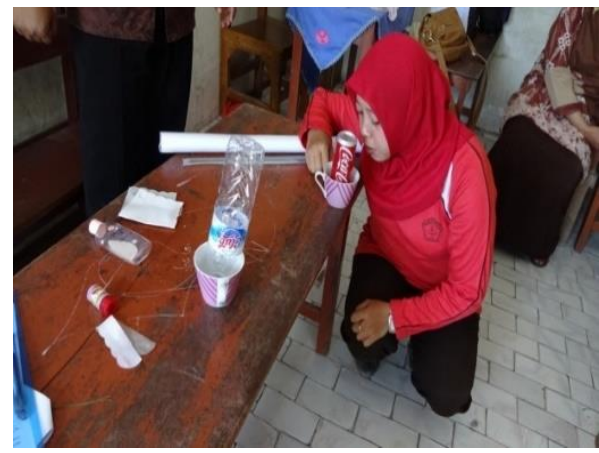

Gambar 3. Praktek Alat Peraga IPA

Berikut hasil dari PKM ini, yaitu: (1) Pelatihan dilaksanakan pada hari Sabtu tanggal 30 Juli 2016 pukul $09.00-16.00$, dengan peserta yang mengikuti pelatihan ini 8 orang guru yang terdiri dari 1 orang guru kelas 1,2 orang guru kelas 3 , 2 orang guru kelas 4,1 orang guru kelas 5,1 orang guru kelas 6, dan kepala sekolah. Selanjutnya, tim PKM memantau penggunaan alat peraga pada proses pembelajaran. Kelas yang disupervisi, yaitu kelas 5 SD di materi bilangan bulat dan kelas 4 SD di materi IPA. (2) Alat peraga yang dilatihkan dapat diterapkan oleh peserta. (3) Peserta mampu membuat satu alat peraga dari bahan-bahan yang telah disiapkan oleh tim PKM, yaitu satu alat peraga matematika di materi bilangan dengan alat peraga kertas lipat dan satu alat peraga IPA, yaitu massa jenis zat cair. (4) Semua peserta mengisi angket dengan ringkasan sebagai berikut: (1) Seratus persen peserta mengatakan kegiatan pelatihan ini sangat bermanfaat dalam upaya mengembangkan diri terutama dalam proses pembelajaran, (2) Seratus persen peserta mengatakan dapat menambah wawasan dalam penggunaan dan pembuatan alat peraga serta mudah dipraktekkan di dalam pembelajaran, (3) Delapan puluh tujuh koma lima persen peserta mengatakan pelatihan saat ini berbeda dengan pelatihan yang lain karena peserta diajak mempraktekkan langsung dan bahan-bahan yang digunakan mudah dan murah serta tidak membahayakan bagi siswasiswi, (4) Seratus persen peserta mengatakan adanya kelanjutan pelatihan dengan tema/materi yang sesuai dengan kurikulum 2013, khususnya dalam menyusun rencana pelaksanaan pembelajaran (RPP) dengan tematik. Hal ini juga terkait dengan alat peraga yang dapat dimanfaatkan dalam proses pembelajaran, dan (5) Seratus persen peserta mengatakan ingin ada pelatihan berkelanjutan dengan tema/materi yang beraneka ragam misalnya tentang pembuatan RPP yang sesuai dengan kurikulum, metode pembelajaran yang 
mudah bagi siswa sekolah dasar serta mengaitkan konsep dengan kehidupan seharihari.

\section{SIMPULAN DAN SARAN}

Pada alat peraga matematika peserta mampu membuat satu alat peraga dari alat dan bahan yang disediakan. Alat peraga yang dibuat untuk materi operasi bilangan bulat. Peserta membuat alat peraga tersebut dari kertas lipat dengan aturan-aturan yang sesuai dengan konsep matematika. Pada alat peraga IPA peserta mampu membuat satu alat peraga dari alat dan bahan yang disediakan. Alat peraga yang dibuat untuk materi tekanan/hukum Archimedes. Peserta membuat alat peraga tersebut dari saos kemasan, air dan botol plastik.
Saran yang dapat disampaikan adalah perlunya menyediakan alat dan bahan yang lebih variatif sehingga peserta dapat lebih banyak membuat alat peraga baik matematika maupun IPA serta menganalisis materi di sekolah dasar untuk menentukan alat peraga yang cocok.

\section{DAFTAR PUSTAKA}

Departemen Pendidikan Nasional, 2006. Pengembangan RPP.

Widiyatmoko, A dan Pamelasari, S.D. 2012. Pembelajaran Berbasis Proyek untuk Mengambangkan Alat Peraga IPA dengan Memanfaatkan Bahan Bekas Pakai. Journal Pendidikan IPA Indonesia, 1(1), 51-56. 